\title{
Biblical cartography and the (mis)representation of Paul's missionary travels
}

\begin{tabular}{|c|c|}
\hline $\begin{array}{l}\text { Author: } \\
\text { Santiago Guija }\end{array}$ & rro $^{1,2}$ \\
\hline $\begin{array}{l}\text { Affiliations: } \\
{ }^{1} \text { Faculty of The } \\
\text { Universidad Pc } \\
\text { Salamanca, Sa }\end{array}$ & $\begin{array}{l}\text { ology, } \\
\text { ontificia de } \\
\text { lamanca, Spain }\end{array}$ \\
\hline $\begin{array}{l}{ }^{2} \text { Department } \\
\text { Testament Stu } \\
\text { Theology and } \\
\text { University of P } \\
\text { Pretoria, Sout }\end{array}$ & $\begin{array}{l}\text { New } \\
\text { dies, Faculty of } \\
\text { Religion, } \\
\text { retoria, } \\
\text { h Africa }\end{array}$ \\
\hline $\begin{array}{l}\text { Research Proje } \\
\text { Project Leade } \\
\text { Project Numb }\end{array}$ & $\begin{array}{l}\text { ect Registration: } \\
\text { r: E. van Eck (i) } \\
\text { er: } 2400030\end{array}$ \\
\hline $\begin{array}{l}\text { Description: } \\
\text { This research i } \\
\text { of the research } \\
\text { 'Hermeneutics } \\
\text { directed by Prc } \\
\text { van Eck, Depar } \\
\text { New Testamen } \\
\text { Literature, Fac } \\
\text { and Religion, } \\
\text { Pretoria, South }\end{array}$ & $\begin{array}{l}\text { s part } \\
\text { project } \\
\text { and Exegesis' } \\
\text { f. Dr Ernest } \\
\text { tment of } \\
\text { t and Related } \\
\text { ulty of Theology } \\
\text { Iniversity of } \\
\text { Africa. }\end{array}$ \\
\hline $\begin{array}{l}\text { Correspondin } \\
\text { Santiago Guija } \\
\text { sguijarroop@ }\end{array}$ & $\begin{array}{l}\text { g author: } \\
\text { rro, } \\
\text { upsa.es }\end{array}$ \\
\hline $\begin{array}{l}\text { Dates: } \\
\text { Received: } 24 \\
\text { Accepted: } 25 \mathrm{~J} \\
\text { Published: } 27\end{array}$ & $\begin{array}{l}\text { May } 2019 \\
\text { une } 2019 \\
\text { Aug. } 2019\end{array}$ \\
\hline $\begin{array}{l}\text { How to cite th } \\
\text { Guijarro, S., } 2 \\
\text { cartography ar } \\
\text { representation } \\
\text { missionary tra } \\
\text { HTS Teologies } \\
\text { Theological St } \\
\text { a5575. https:/ } \\
\text { 10.4102/hts.v }\end{array}$ & $\begin{array}{l}\text { is article: } \\
19, \text { 'Biblical } \\
\text { 1d the (mis) } \\
\text { of Paul's } \\
\text { vels', } \\
\text { Studies/ } \\
\text { udies } 75(3) \text {, } \\
\text { /doi.org/ } \\
75 \text { i3.5575 }\end{array}$ \\
\hline $\begin{array}{l}\text { Copyright: } \\
\text { (C) 2019. The A } \\
\text { Licensee: AOS } \\
\text { is licensed unc } \\
\text { Creative Comn } \\
\text { Attribution Lic }\end{array}$ & $\begin{array}{l}\text { uthors. } \\
\text { IS. This work } \\
\text { ler the } \\
\text { nons } \\
\text { ense. }\end{array}$ \\
\hline Read online: & \\
\hline 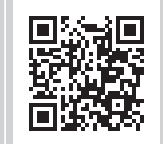 & $\begin{array}{l}\text { Scan this QR } \\
\text { code with your } \\
\text { smart phone or } \\
\text { mobile device } \\
\text { to read online. }\end{array}$ \\
\hline
\end{tabular}

Biblical cartography has elaborated a master narrative of Paul's missionary activity. This master narrative, which clearly distinguishes between three different journeys, is omnipresent and can easily be found in Bibles and atlases. Nevertheless, Paul's letters and the book of Acts do not support such a clear distinction. The present study contends that the distinction between three missionary journeys is a modern construct and that this way of representing Paul's missionary activity has a significant impact on how we understand it. By representing Paul's missionary activity as an orderly sequence of three travels, the maps not only minimise the novelty of his independent mission but also minimise Paul's confrontation with the Jerusalem church. In this representation, he is no longer the marginal leader of a minority movement within the nascent church, but 'the' missionary. The portrayal of the missionary activity of Paul in biblical maps is an example of the uncritical transfer of exegetical traditions, and of the role of these traditions in the creation of a master narrative of Christian origins.

Keywords: Biblical maps; Cognitive cartography; Early Christian mission; Images of Paul; The role of exegetical traditions.

\section{A missionary map in the letters of Paul?}

Paul's perception of geography has only come to us through his letters, where we find references to the places visited by him and his coworkers, as well as the news of some trips he planned and could not carry out. To identify the geographical vision presupposed in them, we may resort to cognitive cartography, a branch of knowledge that studies the mechanisms that control the perception of space. That perception can be disclosed by identifying the cognitive maps presupposed by a text or any other discourse. A cognitive map can be defined as 'a mental model of spatial relations' (Ryan 2003:2015). In the field of narrative criticism, we speak about the implicit author and the implicit reader to refer to the author and reader that a text presupposes. We can also speak about the implicit map to designate the 'mental map that the text creates for its readers' (Alexander 1995a:18). This mental map is a construction, conscious or unconscious, which reflects a vision of geography. To reconstruct this vision, we must identify how places are mentioned and how they are related, as well as the cognitive and emotional connotations that the narrative assigns them.

The mental map of Paul's letters reflects a markedly political vision of geography, as it usually identifies the territories using the names of the Roman provinces (Macedonia, Achaia, Galatia, Judea, Asia, Italia, Hispania, and so on). This geographical construction represents the point of view of Roman authorities and those who could think beyond a local perspective (Meeks 2013:171-172). The letters also mention the names of some cities when they refer to their recipients. The movements of the apostolic group are situated in this mental map.

The letters refer to them in a series of occasional 'travel notes' (Alexander 1995a:20). It is in these notes that we can find some indication of the geographical vision that Paul had of his mission. However, most of them refer to trips between two or more cities and do not reflect an overall vision.

There is only one relevant information about how Paul understood his missionary activity in the past and his plans for the future. It can be found at the end of the letter to the Romans and reflects a crucial moment in his missionary trajectory ( $\mathrm{Rm} \mathrm{15:14-33).} \mathrm{In} \mathrm{this} \mathrm{summary} \mathrm{of} \mathrm{his}$ previous activity and his plans, geography plays a decisive role. The mental map presupposed is

Note: The collection entitled 'Eben Scheffler Festschrift', sub-edited by Jurie H. le Roux (University of Pretoria) and Christo Lombaard (University of South Africa). 
that of the Empire. He mentions several provinces (Illyricum, Hispania, Macedonia) and two cities that have a strategic and symbolic value (Jerusalem and Rome).

Paul talks about two missionary projects. The first, which goes from Jerusalem to Illyricum, belongs to the past. The second, which goes from Rome to Hispania, to the future (Meeks 2013:169).

The first missionary project has a perfect geographical definition: 'so that from Jerusalem and in a circle to Illyricum

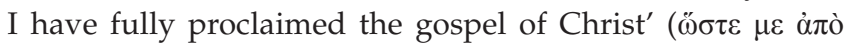

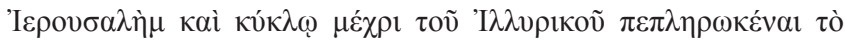

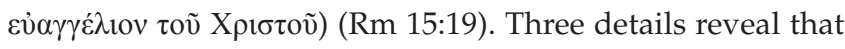
this description reproduces a mental map created by Paul. ${ }^{1}$ Firstly, although he began his mission from Antioch after a harsh confrontation with Peter (Gl 1:22), in this passage, Paul makes it begin in Jerusalem, thus linking it to the metropolis of Judaism. Secondly, Paul mentions in his letters different local travels, but when it comes to summarising his first missionary phase, he represents it as a linear process in a circle. Finally, the reference to Illyricum is also striking, as nothing in his letters suggests that Paul and his coworkers had gone so far.

This sentence reflects a mental map that Paul creates for his readers. In this map, there is no glimpse of different missionary journeys. What Paul had performed up until then was part of a single missionary project that was concluding. The trip to Jerusalem to bring the collection ( $\mathrm{Rm} \mathrm{15:26)}$ was not the end of a supposed missionary journey because the goal of the first mission was Illyricum. That journey to Jerusalem was only a necessary pause to restore communion with the Jerusalem church before heading for Rome, from where he planned to begin a new missionary phase.

The new missionary step also has its mental map. After visiting the Jerusalem community, he would go to Rome and from there to Hispania: 'I will leave for Spain through

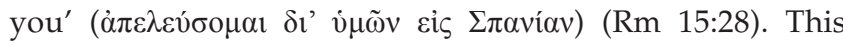
second missionary project is not yet defined in its details, but, as in the first one, Paul is clear about its beginning and end. Within the framework of his missionary plans, the journey to Hispania, in the confines of the world known to him, was necessary for the gospel to reach all the Gentiles $(\operatorname{Rm} 11: 25)$.

Thus, in the cognitive map of Paul's letters, the mental map of the Empire, which had Rome as its centre, is superimposed on the Jewish mental map centred on Jerusalem: from Jerusalem to the Illyricum and from Rome to Hispania (Meeks 2013:173-180). On this map, Paul locates his evangelising activity in the eastern Mediterranean: his first missionary project that seems to have come to an end when he writes Romans.

1.Commentaries usually draw attention to these details not mentioned in the letters or in Acts, but without identifying the process of construction of a mental map; see, for example, Keck (2005) and Penna (2008). For a narrative analysis of the space in Romans, see Gignac (2006).

\section{The map of Paul's mission in Acts}

The cognitive map of Acts, like that of the Pauline letters, has a marked political character. In Luke's story, the territories are also identified by the name of the Roman provinces (Judea, Italia, Macedonia, and so on), although some are mentioned by their informal regional name (Lycia, Pamphylia, Phrygia). Being a story, and not circumstantial letters, the map of Acts is more complex, includes emotional elements and has a more defined point of view (Alexander 1995b:31-45; Kloppenborg 2017:133-140). The maps that reproduce the atlases and the bibles are supposedly based on this narrative. However, there are good reasons to think that the maps determine the reading of Acts and not the other way around.

By the middle of this narrative, we find a first missionary journey of Paul and Barnabas that begins and ends in Antioch (Ac 13-14). The beginning and the end of this trip, as well as its protagonists and the task they carry out, are carefully defined in the story. The beginning of his first mission is the direct consequence of an election of the Spirit. As a result of this election, the missionaries are sent by the community of Antioch (Ac 13:1-3). The end of this mission reproduces almost in a specular way this beginning, telling how the missionaries return to the community that sent them and how they share their missionary efforts with the community (Ac 14:24-28). It was a trip promoted and encouraged by the Antiochene community. Those responsible for carrying it out were Barnabas, leader of the group of teachers and doctors of Antioch, and Saul, who also belonged to that group. Finally, as the narrative unfolds, it will be

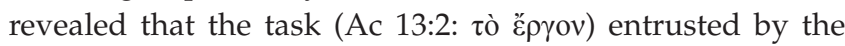
Spirit to them was to open the door of faith to the Gentiles

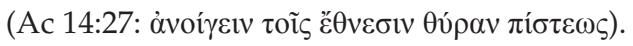

In the dispositio of the book of Acts, this trip introduces one of the crucial moments of the story: the assembly of Jerusalem (Ac 15:1-35). This assembly marks a turning point in the narrative. It legitimates the reception of the Gentiles into the church, thus confirming the mission addressed to them. This new stage, however, will not be carried out by Barnabas and Paul, but only by the latter. Regardless of how Luke explains this fact, what should be noticed here is that a new phase of the story begins, in which Paul, who now acts as an independent missionary, will be the protagonist.

This independent mission of Paul concludes, in the Lucan story, with the discourse to the elders of Ephesus (Ac 20:17-38). The fact that Paul does not return to Antioch after this meeting, but to Jerusalem, reveals that this is a different phase of his missionary activity. Despite this clear indication, it has been common to distinguish in these chapters two missionary journeys that follow a pattern similar to the first one. ${ }^{2}$ This distinction relies on two observations:

2.The following commentaries distinguish three trips: Schille (1983), Mussner (1984) Fitzmyer (1998) and Walaskay (1998). On the other hand, Barrett (1998) and Bock (2007) talk about a section with two trips. 
1. The new journey begins like the previous one: 'after having entrusted them to the grace of God' (Ac 14:26; 15:40).

2. In the course of this new missionary phase, Paul returns to Antioch, which remains a community of reference for him: '[He] went down to Antioch. And after spending some time departed ...' (Ac 18:22b-23a).

These arguments, however, do not support a distinction between two different missionary journeys.

Although Luke wants to give the impression that Paul's new travel is in continuity with the previous one, his visit to the Antiochene community is described in such a generic way ('spending some time') that it is difficult to see the relationship with the journey carried out together with Barnabas. For this reason, most commentators are now reluctant to identify two missionary trips in these chapters and prefer to speak of an 'independent mission', or of the 'Aegean mission', noting that in the Lucan story, after the assembly of Jerusalem, the geographical centre moves from Syria to the Aegean Sea (Marguerat 2015:111). ${ }^{3}$

The account of Acts distinguishes between two missions to the Gentiles. In the first mission, dependent on the community of Antioch, Paul appears as a collaborator of Barnabas, while in the second mission, he is the undisputed protagonist. These two missions presuppose two different maps. In the first one, centred in Jerusalem, the Aegean is a distant place. In the second one, however, the centre has moved precisely to that distant place, and Jerusalem lays in the distant East (Alexander 1995b:30-31). This second map is closer to the one presupposed by Paul's letters, which lacks any reference to the first journey narrated in Acts.

Thus, the book of Acts distinguishes between two phases in the missionary work carried out by Paul, not only by assigning a different role to the apostle and the community of Antioch in each of them but also by placing them in two different mental maps. These differences between the Antiochene journey and the Aegean mission prevent taking the former as a model to identify two different journeys in the second. Therefore, the distinction between three missionary journeys that we find in bibles, atlases and in many commentaries does not come from the Lucan story.

\section{Paul's missionary journeys in the maps}

Bearing in mind the results of the analysis carried out so far and the implicit maps we have identified in Paul's letters and the book of Acts, let us now examine the maps that represent the itinerary of the Pauline mission. They are everywhere: in the bibles and introductory biblical texts, but also in the critical editions and the academic atlases. All of these maps consistently distinguish three missionary journeys of Paul. The New Testament (NT) cartography has managed to elaborate a master narrative of the missionary activity of Paul and has made this narrative a pervasive paradigm, which determines how we read the biblical text.

It will suffice to consult one of the most recent editions of the Nestle-Aland's Greek NT to find this pattern. Different lines of different colours identify four trips of Paul as first journey, second journey, third journey and journey to Rome. Consistently, in the text of Acts, this edition that is so reluctant to introduce paratextual elements as titles or divisions introduces a blank line between Acts 18:22 and 18:23. The impact of the maps has not only shaped the popular editions of the Bible but has even determined the most used critical edition of the NT.

This influence is also evident in academic biblical atlases. After examining a good number of them, I should only mention five of the most recent and prominent, which come from different geographical areas and different academic contexts: The Macmillan Atlas, in its fifth edition (Aharoni 2015:198-190); The Sacred Bridge Atlas of Carta (Rainey et al. 2006:373,375 and 377); The Herder Atlas, a reference in the German language (Zwickel, Egger-Wenzel \& Ernst 2013:304-309); The Oxford Atlas, in its fourth edition (Curtis 2007:167-170) and the most recent one, that of Edizioni San Paolo (Cucca \& Perego 2012:97 and 99). All of them unavoidably identify three missionary journeys of Paul.

The question posed by this overwhelming coincidence is: Where does this cartographic dogma come from? This is a crucial question because this dogma has determined and continues to determine the reading of Acts and the understanding of Paul and his mission. The answer is not in traditional exegesis, but elsewhere.

\section{Where does the three journeys' scheme come from?}

The outline of Paul's three missionary journeys present in some modern commentaries, and dominant in biblical cartography, was unknown to ancient and medieval commentators. Although an in-depth study of ancient commentaries to Acts is still lacking, there are sufficient indications to affirm that this tripartite division of Paul's missionary activity was completely foreign to them.

In a short but thought-provoking article originally published in 1985 in the Seminar Papers of the Society of Biblical Literature (SBL), John Townsend (1986) approached this question. After challenging the three journeys pattern, which by then was accepted almost unanimously by biblical scholars, Townsend proposed an explanation of how it could have originated. His paper went unnoticed in academic literature, but the above observations on the implicit map presupposed in Paul's letters and Acts suggest that his thesis can help to clarify the origin and function of this cartographic representation of Paul's missionary activity. 
After showing that the narrative of Acts does not support this representation, he observes that ancient and medieval commentators were unaware of it. At the end of the $2 \mathrm{nd}$ century, for example, Irenaeus of Lyon gave a detailed description of the itinerary of the Pauline mission. In this description, he does not speak of three journeys, but about a single one with multiple displacements (Adv. Haer. 3,14,1). Similarly, in the old commentaries (Didymus the Blind, Jerome, Hesychius of Jerusalem, Ephrem, Theodore of Mopsuestia and Isho'dad of Merv), as in those of the Renaissance and Reformation (Erasmus, Calvin, Beza, Cornelius a Lapide), there is no mention of three journeys.

Townsend finds the first mention of this 'three-travel pattern' in the first edition of J.A. Bengel's Gnomon Novi Testamenti published in 1742. It became popular among commentators in the following years, and a century later was already firmly established in the exegetical tradition. The data are striking for two reasons. Firstly, because such a pattern had no basis either in the text of Acts or in the old commentaries; and secondly, because this vision of the Pauline mission had enormous success. The inevitable question is then: Why did this scheme have such a success precisely at that time?

Townsend's answer is original and suggestive. His thesis is that this interpretation of Paul's missionary activity is a consequence of the rise of European missionary societies, which became very popular not only in Protestant circles but also among Catholics in the first half of the 19th century. These societies started a missionary model because, unlike earlier missionaries who used to leave for a trip without return, their members were expected to return to the place from where they departed.

The missionary pattern established by these societies was very similar to that of the first missionary journey of Barnabas and Paul narrated in the book of Acts (Ac 13-14). For that reason, it is not surprising that these societies had taken this trip as a model for their missionary journeys: London or Rome was for them the new Antioch. Their experience, so close in this aspect to that of Barnabas and Paul, turned this first trip into a model for the rest of Paul's missionary career.

Townsend is right when he concludes that this pattern reflects a colonial vision. However, it seems that there is much more behind the initial success and subsequent consolidation of the 'three-journeys pattern'. The conscious or unconscious interest to link so closely the two phases of the Pauline mission narrated in Acts reveals the purpose of reinforcing a particular vision of the apostle, a vision that was and is supported by biblical maps.

\section{Maps as instruments of persuasion}

To understand what has been and continues to be the role of biblical maps in promoting a particular image of Paul, it is necessary to realise, in the first place, what is a map.
A working group of the International Cartographic Association proposed the following general and diplomatic definition in 1992: '[A map is] a representation or abstraction of geographical reality: a tool for presenting geographical information in a way that is visual, digital or tactile'. John Harley and others, in their History of Cartography, proposed in 1987 a more specific definition: 'Maps are graphic representations that facilitate a spatial understanding of things, concepts, conditions, processes, or events in the human world' (Wood 1992:66-67).

These two definitions reflect a common doctrine in the field of cartography that emphasises the neutral nature of maps. Although in both definitions, the word 'representation' which easily evokes the idea of 'elaboration' - plays a crucial role, both of them implicitly affirm that this representation accurately reproduces the real world. However, a closer consideration of the function of maps reveals that this view is too naive. Maps are, in fact, powerful instruments of persuasion and power (Wood 1992).

Maps perform three related functions: they objectify, they interpret and they legitimise. By displaying space in its various aspects, maps objectify it and convey a strong sense of realism. However, the very act of representing space or geography is an act of interpretation, which establishes a distance between reality and its representation. Finally, this representation, which is not objective but an act of interpretation, often has a legitimating purpose. Maps do not offer therefore the unbiased objectivity they promise, but a particular vision of reality that is not neutral or innocent at all.

Maps are similar to texts in many ways. As there is a distance between the real world and the texts that represent it, so there is a distance between the geographic realities and the maps that represent them. A story, even if it reports real events, is not an exact reproduction of those events. The act of composing a story necessarily implies an interpretation. Similarly, the elaboration of a map implies a complex process of selection and articulation, which interprets reality to produce an effect on its recipients.

Because of their capacity to objectify and their supposed neutrality, maps enjoy an authority that produces in those who use them a hypnotic effect (Boggs 1947). This authority ascribes to maps a persuasive capacity that makes them a potent instrument of legitimation. How a map fuses and confuses in a single plane complex and varied spatial realities makes it very difficult to distinguish between the reality represented and the world view reflected by the representation. They convey such a sense of integrity and totality that their hermeneutical nature is entirely obscured (Wood 1992:72).

One of the most important consequences of this persuasive power of maps is that they can be used to promote or reinforce a particular vision of geography or history. Biblical cartography is, in fact, an excellent example of this, 
as Burke Long has shown in his study of biblical maps and American nationalist accounts. Maps - he contends - are cultural constructions that 'encode hegemonic scenarios of memory and identity ... that shape the social experience' (Long 2007:110).

The maps of Paul's journeys are also a cultural construction that has shaped the understanding of the apostle and its place in the memory of Christian churches. These maps have an agenda, a programme, which is hidden behind their pretended objectivity.

\section{The hidden agenda of the Pauline maps}

Let us summarise the way travelled so far in this inquiry. We began by observing that neither the implicit map of the Pauline letters nor that of the book of Acts includes three missionary journeys of Paul. In spite of that, biblical maps, even those reproduced by the most prestigious biblical atlases, clearly identify them. This 'three-journey pattern' also appears in some modern commentaries, but there are no traces of it in the commentaries composed before the 18th century. The emergence of this new vision of Paul's missionary journeys coincides with the introduction in Europe of a new model of mission that resembles the first journey narrated by Acts (Ac 13-14). Following Townsend, we have assumed that the legitimisation of this new missionary model could have been the main reason for the success of this model. Nevertheless, the fact that this outline of Paul's journeys has persisted so stubbornly in biblical cartography has alerted us to a possible hidden agenda behind this cartographic dogma.

The letters of Paul offer other clues to understand Paul's mission in a different way. The most relevant data are in Galatians 2, where Paul mentions the agreement reached in Jerusalem: a mission to the Gentiles without any burden (Gl 2:6); as well as his later conflict with Peter (Gl 2.11-14). This conflict was caused by the arrival of the 'men from James' who provoked Peter's change of attitude on the matter of table fellowship between Jews and non-Jews (G1 2:12). As a consequence of this disagreement, Paul and those who agreed with him became a marginal group in the communities that were under the orbit of the Jerusalem church. This fact coincides with the beginning of a new missionary phase centred on the Aegean.

After this conflict, Paul stopped being a missionary fully linked to the mother church and became an independent missionary (Dunn 2009:489-494). Although he never broke communion with that church, his letters reveal that during this period he was anxious about reinforcing (restoring?) that communion, as shows the constant allusions to the collection, which he understood as a sign of communion (1 Cor 16:1-4; 2 Cor 8-9; Rm 15:25-28, 31).

Luke modified this vision of Paul as a marginal missionary. He carefully notes how Barnabas took Paul to the church of
Antioch (Ac 11:25-26), and how Paul became there a member of the group of doctors and teachers (Ac 13:1). He also tells how Paul was chosen by the Spirit to accompany his mentor in the first mission to the Gentiles (Ac 13:2). Moreover, he mentions Paul's visit to Jerusalem (Ac 15, 1-35), although he envisions and narrates these facts from a different point of view shaped by the experience of an entire generation in which Paul's mission had begun to bear fruit.

It is especially interesting to observe how Luke narrates Paul's departure from Antioch after the assembly of Jerusalem (Ac 15:36-41). Luke's story does not mention the disagreement with Peter, nor the real reason for the separation or the role that the Jerusalem church played in it. Although it tells about an intense dispute, the disagreement is only with Barnabas, and the discussion is on whether John Mark should accompany them, or not. Luke has softened the conflict to avoid dissociating Paul from the Antiochene church, whose farewell, as we have seen, is very similar to that of the first journey (Ac 15:40).

The image of Paul's mission in the book of Acts is notably different from what we can infer from the apostle's letters. In the Lukan narrative, Paul is not portrayed as an independent missionary, who returned to Jerusalem fearing that the collection he had gathered with so much effort would not be accepted, and consequently, communion could not be restored (Rm 15:31). In Acts, his connection with Antioch and Jerusalem is never compromised, although the absence of members of these churches during his trial in Jerusalem and Caesarea suggests something different (Ac 21-25). Luke distinguishes two phases in Paul's missionary activity, but he does his best to create links between them. ${ }^{4}$

The cartography of the Pauline mission goes a step further in this same direction. By distinguishing three successive missionary journeys that follow the same pattern, the maps blur the distinction made even by Acts between a first missionary phase of Paul as a missionary sent by the community of Antioch and a second phase as an independent missionary. In relationship to the letters, the alteration is even more drastic, because the scheme of the three missionary trips incorporates elements alien to the mental map presupposed in them, such as the first journey and the distinction of two trips during the missionary activity that developed around the Aegean.

By shaping the various phases of his mission according to the pattern of the first journey narrated by Acts, the maps convey the message that in the second and the third travels, Paul was acting as a missionary sent by the church of Antioch. This representation of his missionary activity makes Paul appear during the Egean mission as a 'central' missionary, a missionary associated with the Jerusalem church. As a result, the impact of his conflict with that church is diminished, and the understanding of his mission is dramatically changed. 4.The image of Paul in Acts is part of a complex process of elaboration of the identity of the apostle that took place in the 2nd century (Pervo 2010). 
He is no longer a marginal missionary, the leader of a minority movement within the nascent church. He becomes a model missionary: 'the apostle'. This representation fits perfectly with the central place Paul had and continues to have in the Christian churches, but does not justice to the historical Paul and the innovative character of his missionary work.

Changing the maps may contribute to a more accurate understanding of Paul's mission. This new cartography should avoid the distinction between a 'second' and a 'third' missionary journey, both of them starting and ending in Antioch. It should also distinguish clearly between the first missionary journey carried out by Barnabas and Paul on behalf of the Antiochene church (Ac 13-14), and the independent mission accomplished by Paul and his coworkers after the Jerusalem meeting (Ac 15.36-20.38). This cartographic representation will be closer to the facts and their early representation in the letters of Paul and the book of Acts.

\section{Acknowledgements Competing interests}

The author declares that no competing interests exist.

\section{Authors' contributions}

I declare that I am the sole author of this research article.

\section{Ethical consideration}

This article followed all ethical standards for carrying out research without direct contact with human or animal subjects.

\section{Funding information}

This research received no specific grant from any funding agency in the public, commercial or not-for-profit sectors.

\section{Data availability statement}

Data sharing is not applicable to this article as no new data were created or analysed in this study.

\section{Disclaimer}

The views and opinions expressed in this article are those of the authors and do not necessarily reflect the official policy or position of any affiliated agency of the authors.

\section{References}

Aharoni, Y., 2011, The Carta Bible atlas, 5th edn., Carta, Jerusalem.

Alexander, L., 1995a, 'Narrative maps: Reflections on the toponymy of Acts', in M.D. Carroll, D.J.A. Clines \& Ph. R. Davies (eds.), The Bible in human society: Essays in honour of John Rogerson, pp. 17-57, Academic Press, Sheffield.

Alexander, L., 1995b, 'In journeying often: Voyaging in the Acts of the Apostles and in Greek romance', in C. Tuckett (ed.), Luke's literary achievement: Collected essays, pp. 17-49, Bloomsbury, Sheffield.

Barrett, C.K., 1998, A critical and exegetical commentary on the Acts of the Apostles, T\&T Clark, Edinburgh.

Bock, D.L., 2007, Acts, Baker, Grand Rapids, MI.

Boggs, S.W., 1947, 'Cartohypnosis', Scientific Monthly 64(6), June, 469-476.

Cucca, M. \& Perego, G., 2012, Nuovo atlante biblico interdisciplinare: Scrittura, storia, geografia, archeologia e teologia a confronto, San Paolo, Cinisello Balsamo.

Curtis, A.H.W. (ed.), 2007, Oxford Bible atlas, 4th edn., University Press, Oxford.

Dunn, J.D.G., 1996, The Acts of the Apostles, Eerdmans, Grand Rapids, MI.

Dunn, J.D.G., 2009, Christianity in the making. Volume 2: Beginning form Jerusalem, Eerdmans, Grand Rapids, MI.

Fitzmyer, J.A., 1998, The Acts of the Apostles, Doubleday, New York

Gignac, A., 2006, 'Espaces géographiques et théologiques en Rm 1:1-15 et 15:14-33: Regard narratologique sur la topologie paulinienne', Biblical Interpretation 14(4), 385-409. https://doi.org/10.1163/156851506777825269

Johnson, L.T., 1992, The Acts of the Apostles, Liturgical Press, Collegeville, PA.

Keck, L.E., 2005, Romans, Abingdon Press, Nashville, TN.

Keener, C.S., 2014, Acts: An exegetical commentary: 15:1-23:35, Baker, Grand Rapids, MI.

Kloppenborg, J.S., 2017, 'Luke's geography: Knowledge, ignorance, sources, and spatial conception', in J. Verheyden \& J. Klopenborg (eds.), Luke on Jesus, Paul, and earliest Christianity. What we really know?, pp. 101-143, Peeters, Leuven.

Loisy, A.F., 1920, Les actes des apôtres, Emile Nourry, Paris.

Long, B.O., 2007, 'Bible maps and America's nationalist narratives', in J.L. Berquist \& C.V. Camp (eds.), Constructions of space I: Theory, geography, and narrative, pp. 109-125, T\&T Clark, New York and London.

Lüdemann, G., 2005, The Acts of the Apostles: What really happened in the earliest days of the church, Prometheus, Amherst, MA.

Marguerat, D.L., 2015, Les Actes des apôtres, Labor et Fides, Genève.

Meeks, W.A., 2013 'From Jerusalem to Illyricum, Rome to Spain: The world of Paul's missionary imagination', in C.L. Rothschild \& J. Schröter (eds.), The rise and expansion of Christianity in the first three centuries of the common era, pp. 167-181, Mohr Siebeck, Tübingen.

Mussner, F., 1984, Apostelgeschichte, Echter, Würzburg.

Penna, R., 2008, Lettera ai romani: III. Rom 12-16, Dehoniane, Bologna.

Pervo, R.I., 2009, Acts : A commentary, Fortress, Minneapolis, MN.

Pervo, R.I., 2010, The making of Paul, Fortress, Minneapolis, MN.

Rainey, A.F., Uzziel, J., Schultz, B., Shai, I. \& Notley, R.S., 2006, The sacred bridge: Carta's Atlas of the Biblical world, Carta, Jerusalem.

Roloff, J., 1981, Die Apostelgeschichte, 17th edn., Vandenhoeck \& Ruprecht, Göttingen.

Ryan, M.L., 2003, 'Cognitive maps and the construction of narrative space', in D. Herman (ed.), Narrative theory and the cognitive sciences, pp. 214-242, CSLI Publications, Stanford.

Schille, G., 1983, Die Apostelgeschichte des Lukas, Zwingli, Berlin.

Spencer, F.S., 1997, Acts, Academic Press, Sheffield.

Townsend, J.T., 1986, 'Missionary journeys in Acts and European missionary societies', Anglican Theological Review 68(1), 99-104.

Walaskay, P.W., 1998, Acts, Westminster-John Knox, Louisville, KY.

Wood, D., 1992, 'How maps work', Cartographica 29(1), 66-74. https://doi.org/ 10.3138/H314-J2NG-Q543-5633

Zwickel, W., Egger-Wenzel, R. \& Ernst, M., 2013, Herders neuer Bibelatlas, Herder, Freiburg. 